Article

\title{
From TOD to TAC: Why and How Transport and Urban Policy Needs to Shift to Regenerating Main Road Corridors with New Transit Systems
}

\author{
Peter Newman ${ }^{1, * \mathbb{C}}$, Sebastian Davies-Slate ${ }^{1}$, Daniel Conley ${ }^{2,3}$, Karlson Hargroves $^{1}$ and Mike Mouritz ${ }^{1}$ \\ 1 Curtin University Sustainability Policy Institute (CUSP), Curtin University, Perth, WA 6102, Australia; \\ sebastian.davies-slate@curtin.edu.au (S.D.-S.); charlie.hargroves@curtin.edu.au (K.H.); \\ mike.mouritz@curtin.edu.au (M.M.) \\ 2 School of Civil, Environmental \& Mining Engineering, University of Adelaide, Adelaide, SA 5005, Australia; \\ daniel.conley@adelaide.edu.au \\ 3 Entrepreneurship, Commercialisation and Innovation Centre, University of Adelaide, \\ Adelaide, SA 5005, Australia \\ * Correspondence: p.newman@curtin.edu.au; Tel.: +61-8-9266-9032
}

check for updates

Citation: Newman, P.; Davies-Slate, S.; Conley, D.; Hargroves, K.; Mouritz, M. From TOD to TAC: Why and How Transport and Urban Policy Needs to Shift to Regenerating Main Road Corridors with New Transit Systems. Urban Sci. 2021, 5, 52. https:// doi.org/10.3390/urbansci5030052

Academic Editor: Pierfrancesco De Paola

Received: 7 June 2021

Accepted: 2 July 2021

Published: 7 July 2021

Publisher's Note: MDPI stays neutral with regard to jurisdictional claims in published maps and institutional affiliations.

Copyright: (c) 2021 by the authors. Licensee MDPI, Basel, Switzerland. This article is an open access article distributed under the terms and conditions of the Creative Commons Attribution (CC BY) license (https:// creativecommons.org/licenses/by/ $4.0 /)$.

\begin{abstract}
The need for transit oriented development (TOD) around railway stations has been well accepted and continues to be needed in cities looking to regenerate both transit and urban development. Large parts of suburban areas remain without quality transit down main roads that are usually filled with traffic resulting in reduced urban value. The need to regenerate both the mobility and land development along such roads will likely be the next big agenda in transport and urban policy. This paper learns from century-old experiences in public-private approaches to railway-based urban development from around the world, along with innovative insights from the novel integration of historical perspectives, entrepreneurship theory and urban planning to create the notion of a "Transit Activated Corridor" (TAC). TACs prioritize fast transit and a string of station precincts along urban main roads. The core policy processes for a TAC are outlined with some early case studies. Five design principles for delivering a TAC are presented in this paper, three principles from entrepreneurship theory and two from urban planning. The potential for new mid-tier transit like trackless trams to enable TACs is used to illustrate how these design processes can be an effective approach for designing, financing and delivering a "Transit Activated Corridor".
\end{abstract}

Keywords: transit; entrepreneurship; rail; effectuation; entrepreneur rail model; finance; PPP; transitactivated corridor; corridor transit; urban planning

\section{Introduction}

Transit oriented development (TOD) [1,2] and transit adjacent development (TAD) [2,3] are current terminology in transport and land use planning with TAD being called "TOD gone bad" by Reconnecting America [4]. Others have suggested transit and joint development (TJD) as a concept needed to bring together the necessary public and private sector development opportunities [5]. All of this literature and practice is based on single entity developments around individual stations. This paper introduces the concept of a "Transit Activated Corridor" (TAC), which emphasizes the role of transit in enabling denser development along a whole corridor with a series of station precincts, or TODs. It seeks to help define how the concept of a TAC can be done through a novel integration of three theoretical approaches: from historical analysis of how transport creates land value; how entrepreneurship theory can enable the approaches to tapping that value; and how urban planning tools can enable it to be designed, financed and delivered providing both effective corridor transit and high-quality station precincts. 


\section{Theoretical Basis 1: Historical Analysis of Transport and Land Value}

Effective and efficient corridor transit infrastructure is a key part of a growing city, with numerous cities across the world rediscovering transit's economic value after decades of automobile dependence [6]. The effects of the COVID-19 pandemic on transport intensity, and, therefore, emissions and traffic fatalities, has reinforced the potential of moving away from automobile-dominated transport planning. This new market is being driven by the fact that transit is becoming faster than traffic in most cities and thus providing cities with the option to deliver transit services that are less welfare oriented [7]. In many cases this is a return to the past when railway projects around the world were used to unlock new development opportunities, such as the privately-operated trams and trains of the 19th and early 20th century that were used by most major cities to create real estate opportunities [8]. These were typically entrepreneurial projects funded by the private sector and this approach can be traced as far back as the horse-drawn carriages that ran from the 17th century, through to the tram era and omnibus projects in New York city in the 1820s [9].

Britain's railway expansion in the 19th century and early 20th century was almost entirely led by private entrepreneurs, which resulted in an extensive rail network. Both rail and tram corridors were built primarily as private real estate ventures based on the land value unlocked by the new transit technology. This approach was replicated in many cities around the world as the basis for expanding mobility and settlements for the next 100 years. Some countries took a more public-led approach that lagged behind the British success, such as the French who relied on state-led planning of routes and facilities before engaging the private sector [10].

In many cities the legacy of the entrepreneurial rail era is a medium density urban fabric that follows corridors out from the traditional walking fabric town center; despite many of the railway lines since being taken up these corridors are still quite distinct and given the levels of accessibility that were created often represent higher than average real estate prices with a substantial proportion of the city's knowledge economy jobs [11]. The benefits of transit and walking urban fabric are now one of the driving forces as to why cities are seeking to build more transit down corridors and are wanting more TODs instead of outer area urban sprawl. Hence there is a growing demand for Transit Activated Corridors that deliver both effective transit and cost-effective dense urbanism.

The problem in the recent decades of building railway infrastructure is that it has been built much like freeways, as transport engineering projects only. This is understandable as transport engineering from the 1940s was built around the notion of freeing up congestion by building extra road capacity for automobiles. The new era of cars and buses saw cities spread outwards from the old tram and train lines which were either closed or made part of a welfare-oriented "public" transport system [7]. Thus, the previous approach to transport as being transit integrated with private land development was largely abandoned in favor of government funded freeways and then government funded rail projects. Their value was measured mostly in time savings.

The freeway approach has dominated urban growth until more recent times when sprawling outer suburbs could no longer be effectively serviced by roads and automobiles as congestion levels and average trip times were rising to a level that called for an alternative solution [7]. Whilst many planners like Calthorpe (1993) [1], Newman and Kenworthy [7], Dittmar and Ohland [12], with the Congress of New Urbanism, called for transit oriented developments (TODs) as a solution to this problem, there was little that could happen until rail transit began to be refurbished and new lines installed. Building new rail lines, both heavy rail and light rail, accelerated in the early part of the 21st century, especially in China and India, along with virtually all major developed cities; this has become known as the "Second Rail Revolution" [7].

However, delivery of contemporary transit did not always involve TODs as the mind set and institutional setting of these transport projects was often focused on only the transit solution to time savings and not on land use outcomes, similar to the way of building a 
freeway. Planning and delivery of TODs was often seen as an optional extra and usually only associated with one or two station precincts while the rest was TAD or park and ride [13]. Thus, urban sprawl was not always reduced as dense urban regeneration around new rail stations often remained marginalized in favor of parking. Thus, the goal of achieving more urban fabric in transit corridors and more walkable urban fabric in TODs has not been as successful as hoped when the rail revival happened. It is possible to make a case for such "freeway-like" rail projects for fast trains servicing outer suburbs without proper transit options [14], but there remain real challenges in stimulating urban regeneration in inner and middle suburbs.

Such transit adjacent development, or isolated TODs, is inevitable if funded entirely by governments as they are typically not able to leverage the land development being implemented around stations as a primary funding source. This suggests a re-invention of the historic approach to building transit as a partnership with the private sector through land development.

With a growing market for fast, high quality transit the idea of bringing in private funding has become more obvious for cities that are growing rapidly [15]. The obvious mechanism is through land development rather than just fare box returns which often do not cover the cost of operation. In Chinese cities, land value capture to fund transit is commonplace [16].

Integrating TODs, or station precincts, into a transit system from the start to enable funding of the transit, as well as urban regeneration along a corridor is therefore of growing interest. This approach we have called the Entrepreneur Rail Model [13] and the core principles are outlined below. Hong Kong and Japan use this approach and more recently interest in using private investment has grown with new mid-tier transit technologies like the trackless tram showing the potential for a low-cost urban regeneration catalyst [17]. The success of the Brightline private rail project in Florida has shown that the approach can work in more car dependent cities and regions; this is funded and financed through land development and fare box returns and has begun an extension, and a new, unconnected line, with plans to extend into 20 other cities. Although not an urban TAC but a regional rail corridor the same approach has been used to generate funding and financing from the associated land value around stations.

This paper seeks to show how the Entrepreneur Rail Model approach could be mainstreamed and extended into planning systems to design, finance and deliver Transit Activated Corridors (TACs). The paper suggests how insights can be gained from entrepreneurship practice-based theory and urban planning tools that favor the combination of transit that is designed to deliver reasonable speed along the corridor and walkable station precincts.

In the current approach to building transit (Figure 1) government transport agencies forecast transit numbers based on current and forecast development in the corridor, then set the route and station locations based on the least resistance and least costs, and then finally seek funding from government. In this approach, under-developed land in the corridor can be over-looked as these areas do not currently generate transit demand and the potential to merge the transit and land development interest can be largely lost. If funding is achieved using this approach, new land use opportunities are considered last when the value of the land has already increased following the construction of the transit infrastructure and there is less profit margin for land developers, and no incentive to invest in the transit infrastructure.

Instead, an ERM-based approach (Figure 2) would suggest that rather than beginning with a pre-determined route and station configuration, governments could harness available means by drawing on the private sector to develop a number of proposals for transit service configurations within a broader corridor based on the uplift potential of available land and development sites—or a private proponent could make an unsolicited bid to government to harness such potential. This way partnerships can be formed that include local governments that can often foresee development opportunities and with pri- 
vate developers who make their living out of recognizing good value urban development opportunities. The goal is to harness the available means, both the expertise of the municipality and the private sector and the physical assets themselves in the corridor, to propose transit configurations that create sufficient development opportunities to allow investment in transit infrastructure, while also satisfying the corridor's transport needs. This process can also make use of under-developed public land. Hence in this approach the first step is to identify uplift potential from transit services along the corridor, to then leverage this to secure financing, finally followed by design of the most appropriate transit configuration.

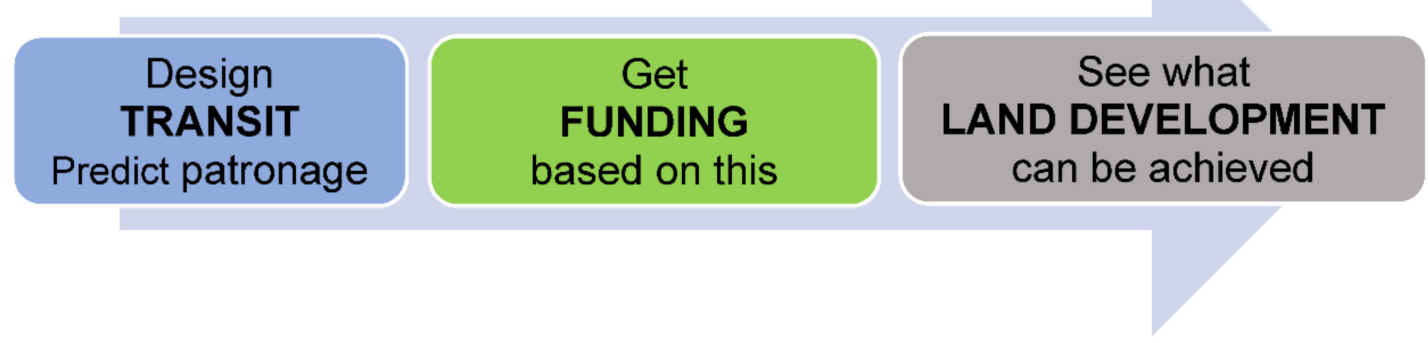

Figure 1. A schematic representation of a typical corridor transit planning process. Source: [13].

Figure 2. A schematic representation of an entrepreneurial approach to the corridor transit planning process. Source: adapted from [13].

The synergy created through such an entrepreneurial approach where the new land development is made viable because the new transit station makes it accessible, is one which aggregates both commuters and customers. In turn new developments attract more people to use the transit system, a mutually reinforcing relationship that sees more people opt for shared transit rather than private vehicles-forming a strong business case for greater development (rather than land-based charges that make it more expensive to be located near a station whether it delivers value or not). When developers are given the opportunity to co-locate stations with office complexes or choose land parcels in areas with greater need for more office space, there are compounding benefits across many financial and livability measures when compared to development "added" after transit is provided [18]. This approach to building transit down a whole corridor of TODs used to fund and finance it, is the approach adopted by Hong Kong in its MTR, and by Japan in projects such as the new Tsukuba Express Line and more recently in China.

\section{Theoretical Basis 2: Entrepreneurship Theory for Transit Activated Corridor Development}

The historical analysis shows that the transit-oriented, dense urbanism developed from the mid-19th to mid-20th century was created by entrepreneurs along corridors. Thus, 
it would appear sensible if this urban fabric is again on the agenda for 21st century cities to understand the role of entrepreneurs in creating TACs.

The study of entrepreneurship is a growing discipline, mostly focused on individual start-up approaches for new businesses, with a lack of consensus on the definition and practice of the knowledge in the field $[19,20]$. There is general agreement however that a core feature of the practice of entrepreneurship is creating value, often under conditions of uncertainty, and typically to obtain private wealth [19] though not without seeing its public benefits. Thinking of entrepreneurship as a process of value creation has led to its broadening beyond just start-up individuals, and towards the traits and approaches sometimes displayed by government and civil society, termed "Entrepreneurial Governance" [21-23]. Similarly, Harvey [24] presented "urban entrepreneurialism" as urban governance that increasingly focuses on "new ways in which to foster and encourage local development and employment growth".

Rather than thinking of "entrepreneurial approaches" as purely strategies that are applied by individuals or start-ups seeking to grow profitable companies, these approaches can also be used to create value in the form of jobs and wealth, improved use of public space, reduced environmental pollution, alleviating congestion, and delivering cleaner and more efficient cities [25]. In the same way, this paper refers to principles of entrepreneurship to outline the process of entrepreneurially activating corridors using new transit lines-given the entrepreneurial legacy of this process throughout history.

The entrepreneurship literature that seems to provide the greatest guidance on how to achieve the entrepreneurial approaches required for TACs and to provide the most potential to further enhance its application, is called "Effectuation" [26]. According to Sarasvathy, effectuation is a logic used by entrepreneurs during new venture creation under conditions of uncertainty and involves a number of key principles with three particularly relevant to TACs and the Entrepreneur Rail Model: create partnerships from the start; value creation rather than prediction; and begin with available means rather than pre-determined ends [26].

\subsection{Principle 1: Create Partnerships from the Start}

The first principle drawn from effectuation is to build a group of partners and stakeholders from the beginning, reducing uncertainty and risk as a co-created vision is developed between all parties and is realized through collaboration [26]. Just as expert entrepreneurs build partnerships from the start, an ERM or TAC project would begin with a partnership between land interests, communities, local authorities and financiers, and then reaches agreement with government. Effectuation suggests that "self-selecting stakeholders" tend to have more commitment to the project; and in the case of private funding and financing of urban rail projects, self-selecting stakeholders are often able to reach agreements around the distribution of benefits and costs more easily [27].

These partnership-first approaches have been growing rapidly around the world in recent years, taking the place of siloed professional practice [28]. For cities and infrastructure, this partnership approach has sometimes been called a "City Deal", and enables a more bottom-up approach to infrastructure planning and provision. These new approaches will be important for involving private funding to help fund the capital costs involved in quality transit projects [13]. The Australian Federal Government has followed the success of the UK City Deal policy and has created a program based on this concept to encourage urban renewal, that includes a focus on urban rail [29]. The program offers financial risk guarantees rather than contributing direct funding, reducing the risk for private sector involvement. The City Deal program includes requirements to enable [30]:

- An agreement between the three tiers of government, setting out a plan for the City Deal,

- Greater community involvement and support for any projects, and 
- Involvement of the private sector, including innovative financing that integrates transit and land development, and with supporting funds from local and state government, with the federal government providing a risk guarantee.

The United Kingdom's City Deal approach began as part of an agenda to devolve power from the national government to city governments, with the aim of boosting economic growth. This began with a first wave of the eight largest city economies in England, outside of London. The Manchester City Deal was notable for its "earn back" feature, which allowed the local authority to retain part of additional tax revenue gained from investments connected with the City Deal [31]. This is akin to tax increment financing, combined with central government funding, and does not involve the entrepreneurial approaches as outlined in this paper. Since then, the City Deals have become more entrepreneurial.

The approach to the City Deal program in Australia was analyzed by Clark and Moonen [32] and involves an integration of policies related to providing infrastructure and urban planning with private sector land development in order to create "great cities". It requires governments at all levels to set up partnerships with private financing, especially superannuation companies looking for long term investments, developers who understand markets and innovation in urban development, as well as communities who know what they prefer in their precincts and neighborhoods for the long term [28,30]. The partnerships enable the best economic value creation by facilitating social capital, financial capital and political capital as explained in Newman and Kenworthy [7]—-see Figure 3.

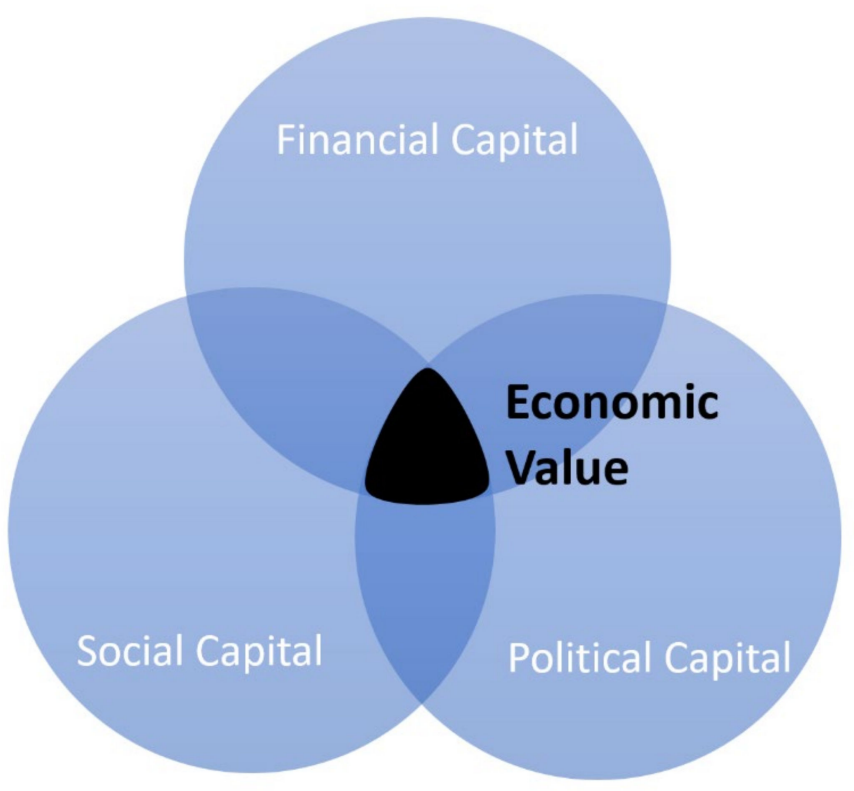

Figure 3. Economic value creation through integration of financial, social and political capital—the intention of a "City Deal". Source: [7].

Another key feature of the City Deal approach is it provides an effective mechanism to align the policy intent of the different tiers of government. This provides greater clarity to the private partner, reducing risk, and facilitates co-ordination with other government programs, see Figure 4. 


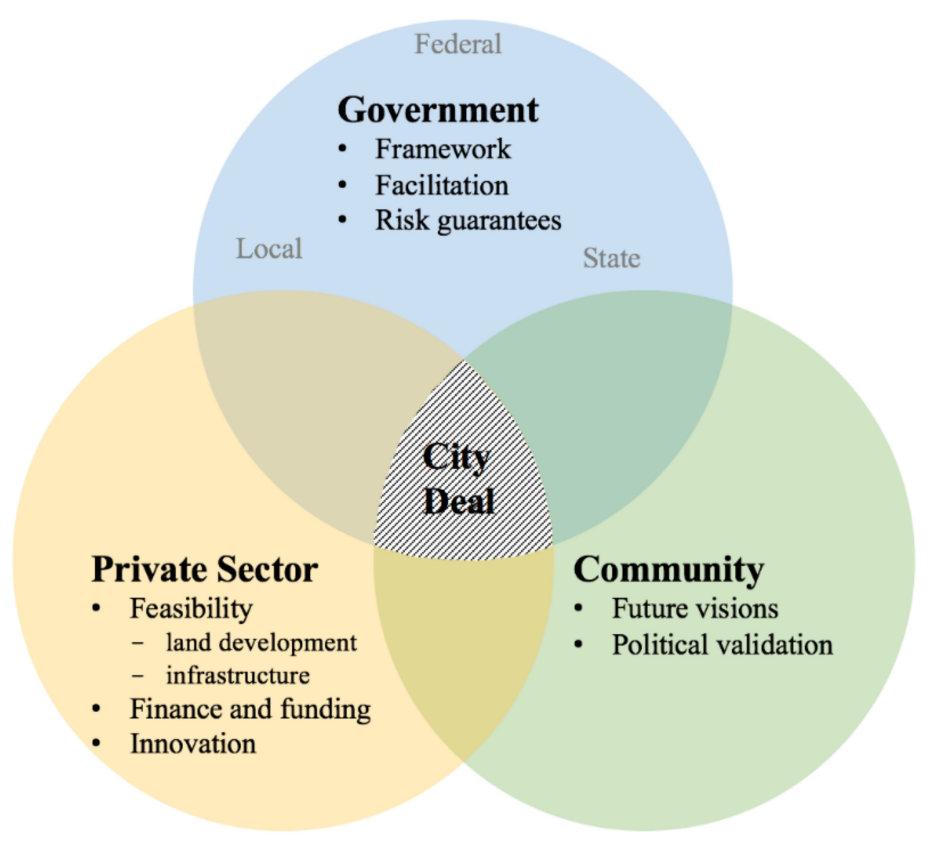

Figure 4. The City Deal partnership model. Source: [7].

This key feature of a City Deal, the alignment of multiple tiers of government, community and the private sector, can be seen to various degrees in existing rail projects around the world, including:

- The Tsukuba Express project in Japan, which came about as a result of long-term government strategic planning. It was delivered on commercial terms by a specially constituted company with ownership shared between city, prefectural and metropolitan governments along the route, and the private sector. The central government provided concessional financing to support the project, but it was delivered by a private company [8].

- The Indian Government's Metro Rail Policy, which sets as a requirement of central government support of a project that it includes private participation, and also must consider the potential for private funding contributions and transit-oriented development. The implementing agencies are also encouraged to maximize project revenue from commercial real estate development at the stations and other non-fare box revenue. Metro rail is seen as a means to achieving sustainable development and a more compact urban form and the mechanism for delivery includes the Urban Mass Transit Company which is a 50:50 government and private agency that has flexibility in raising finance as well as enabling assessments of Metros [33].

- London Crossrail-a project jointly funded by private interests, the Greater London Authority and the national Department for Transport with partnerships developed through the Infrastructure and Projects Authority which is a national government advisory group establishing PPP to enable the funding and financing of infrastructure [8].

City Deals are well-suited to facilitating Transit Activated Corridors, as they can provide increased regulatory certainty or guidance along the corridor, by aligning the objectives of the different tiers of government and can enable the private sector to obtain their finance. In Australia this involves an Infrastructure and Projects Finance Authority that operates in parallel to the assessment process through Infrastructure Australia. At state and local level where detailed planning is done, this would include environmental approvals, land use planning changes, reduced parking requirements and appropriate regulatory approvals in transport, including rail safety regulation. Agreements can also be reached with multiple levels of government to provide associated public infrastructure work such as recharge services for stations where electric battery recharging is needed. 


\subsection{Principle 2: Value Creation Rather Than Prediction}

The second principle drawn from effectuation is to focus on what can be controlled to "create value" rather than to act based upon "predicted outcomes". In practice, according to Sarasvathy [26], this means expert entrepreneurs focus on the controllable aspects of an unpredictable future rather than acting based on predictions of an uncertain future. Some of the mechanisms for capturing value created by the transit system are set out in Newman et al. [7], including the highest value-producing mechanism of a fully private entrepreneurial approach through to the lowest value-producing fully public approach with various levels in between.

Currently, transit corridors are assessed based on predicting the number of people who would potentially use a new mass transit system based on present land use and travel patterns and seek to finance this through public funds or additional rents and landbased charges imposed on surrounding landowners. Traditional government funded value capture approaches rely on a "predicted return", whether this be a predicted number of passengers, a predicted reduction in congestion, or a predicted amount of development and thus value capture can be managed; however, most of the value leaks as soon as a route and set of station locations with density zoning is made public by government, unless partnerships with entrepreneurs are made at the planning stage. There is also an issue with prediction. Transport planners have struggled with prediction, particularly for road networks, due to the principle of induced demand which causes unexpected behavior from commuters when new travel options become available [34]. A prime example of this is that despite providing additional vehicle lanes to relieve congestion, the new lanes are unable to provide lasting congestion relief, due to travelers shifting travel times, routes and modes when networks are changed, even slightly. This is referred to by Downs [35] as the theory of triple convergence and it leads to ineffective prediction-based interventions. This effect can also occur when forecast-based transit interventions deployed in isolation of land development are undertaken and can result in less-than-expected reduction in traffic congestion [36]. Means of overcoming this in Europe are set out in Principle 4 using Sustainable Urban Mobility Plans.

The Entrepreneur Rail Model however creates Transit Activated Corridors through a focus on creating complimentary opportunities for both new land use investment and increased transit ridership, resulting in greater urban densification and less urban sprawlwhich is not possible through current transit planning. This is made viable through integration of private land development with transit services to create station precincts which creates two increased sources of value: one is due to the land value increases of between $20 \%$ and $50 \%$ usually associated with transit (summarized in [13] which enables higher density development, and second, a reduced need for expensive car parking infrastructure of around 20\% which enables better urbanism [7]. The result of greater value increase is that it can also mean investment to construct the transit infrastructure, so the value is created. It is in this way that the entrepreneurial approach "creates new markets" that government planners cannot achieve on their own. This value increase can only be achieved in partnership with governments that manage the common good outcomes necessary but are freed from the need to raise all the funds.

This entrepreneurial approach was used by Hong Kong in its metro and in the development of the private suburban railways in Japan, primarily in the first half of the Twentieth Century. Railway companies augmented their transport revenue through real estate development and management, but also proactively managed land uses around their stations to influence passenger demand. Land was provided to institutional users such as hospitals or universities at concessional rates at the outer terminal stations, creating demand for travel in the reverse direction from central business district commuting patterns [37]. The private railways had to diversify in this way to survive, as the Japanese Government had partially nationalized the industry to create the Japan National Railway. Private companies were forbidden from building railways which interfered with the national railway's operations and were mostly restricted to areas with low population. This forced them to build their 
own catchment population around their railways [38], making the best use of the assets at their disposal. This is a good example of a TAC that was privately created but had significant benefits to the wider community. Similar results, albeit with less striking development histories, have taken place in Hong Kong, and more recently, has begun to take place in mainland China.

Thus, value creation can be applied to the TAC model using value uplift in land development to create value for the transit funding, rather than the value capture or value leakage that occurs under the present approach to "predict and provide" transit, leading to limited interest in transit projects.

In cities that do not have such attractive land development potential as does Hong Kong and Japan, this approach can be taken a step further to attract private investment in transit infrastructure. Rather than just buying pre-rail land and selling it at post-rail prices, the partnerships with landowners and developers can be expanded to capture even greater value around stations. This can be done by incorporating developer preferences for the location of the transit line and associated stations to allow for fully private transit lines to be constructed and operated in unison with new developments [8]. Coupled with this, there are technological innovations occurring in the transport technology sector that are providing rail-like solutions at a much cheaper cost, discussed below.

Such an approach stands to provide cities and nations with a way to break out of the gridlock of automobile dependence and under-financed transit by harnessing private investment to deliver integrated transit and land development along corridors. This way enables value creation from the transit that can be used to contribute to the costs associated with delivering the transit without driving away investors and developers.

\subsection{Principle 3: Begin with Available Means Rather Than Pre-Determined Ends}

The third key principle drawn from effectuation is to "begin with a set of available means, rather than pre-determined ends" [26]. This requires thinking differently about what constitutes a cornerstone for action, innovation and finance. During new venture creation, expert entrepreneurs tend not to decide upon a "final product" and then seek to assemble the required resources, but instead begin with what is available, giving preference to actions which harness available resources or networks and which appear to help with their perceived journey.

Unlike the current approach to transit which seeks to predict and build transit infrastructure based on current conditions and reliant on government funding, this principle suggests that instead of using a pre-determined route and trying to "add on" land value creation at the end, the "available means" or available land opportunities are in fact the basis for the viability of the entire project and need to be considered right from the start.

Despite entrepreneurs often being considered "risk takers", expert entrepreneurs seek to minimize risk by "controlling the downside scenarios and finding ways to reach the market with a minimum expenditure of such resources as time, effort and money" [26]. This means entrepreneurs seek to creatively leverage underutilized or "slack" resources, such as land development sites that can be made viable through transit accessibility. Such development opportunities can then provide a powerful dynamic in the process to design and deliver transit infrastructure. Hence, rather than having a fixed route and set of station locations in mind, the process can begin with a configuration that best leverages investment in the early stages. As station precincts then begin to be built and create more value, the investment in the transit can continue to grow to provide greater services and station precinct locations. Organic growth of a TAC project can be based on stages that depend on what the land development market can achieve.

Examples of this organic process of beginning with what is available can be seen in the United States in the development of new corridor rail lines based on a series of TODs builtin stages. Organic stepwise approaches to US transit and land development are usually based on entrepreneurial land developers linked in partnership through mechanisms like Tax Increment Financing or Business Improvement Districts. TIF projects raise bonds 
based on estimated future tax revenue developed from successful urban development. Business Improvement Districts (BIDs) are more directly involving contributions from business and have mostly been used to regenerate urban areas though they are now being extended along a corridor. While BIDs do involve new levies, they are either initiated by, or negotiated with, local businesses who will benefit from the infrastructure.

Four examples of such organic TAC-like delivery are outlined.

\subsubsection{San Francisco}

A BID in the Bay Area established a local committee of the district's residents, business owners, tenants, schools and developers, creating a strong base in social capital. The committee prepared a local development proposal including a financial plan and sought approval from local government authorities thus generating the political capital. In this case however, the district residents were charged with elevated property taxes to fund the infrastructure to help regenerate their area. This consensual charge generated the financial capital, rather than leveraging land value uplift to attract new investment [39].

\subsubsection{Pearl District Streetcar}

The Portland MAX Light Rail, or Metropolitan Area Express, was a fully government funded project from the 1980's and was so successful that various other communities wanted to have a similar urban renewal process in their area. The Pearl District of Portland was an old industrial area-creating "available means" for urban regeneration, with businesses and residents wanting a modern transit service to link them to the city center. An organic process was begun in the 1990's to generate a variety of funding sources including a Tax Increment Financing (TIF) set up through the local council (providing 13\% of funding) and a BID-style "Local Improvement District Levy" on local business (providing 17\% of funding) in partnership with state and federal funds. The first two stages of the Portland Streetcar opened in 2001. One further stage was extended in 2007 using $21 \%$ TIF funding and $31 \%$ BID funding as the success of the first two stages had raised land values.

When the Pearl District was legally formed in 1998 the value of property was estimated at $\$ 446$ million and in 2014 at $\$ 2.2$ billion. The tram system for the Pearl District is owned by the City of Portland and managed by Portland Streetcar Incorporated, a non-profit public benefit corporation whose board of directors report to the city's Bureau of Transportation. The Pearl District corridor that is serviced by this light rail is an outstanding success story of urban regeneration with multiple sustainability out-comes [40-43].

\subsubsection{South Lake Union Streetcar, Seattle}

The South Lake Union Streetcar project was initiated by community and business interests working together over several years. The prospect of urban renewal opportunities being generated by a light rail service was embraced by a range of businesses and residents who lobbied for the return of the historic tram car service. The South Lake Union Streetcar project was able to attract the interest of local, state and federal governments who worked out how to fund the project with the local business community. A fee from 760 land parcels was estimated to provide 52 percent of the total project cost. The City of Seattle issued government bonds to raise capital and linked them with the private funds. The city assessed a fee in 2004 and landowners in the precinct approved it in 2005. The street car project became operational in 2007. The assessed fee was based on estimated land value uplift for various land uses. The land owners were provided an option to pay a fee up front or in 18 years at a $4.4 \%$ interest rate. In this case the project was considered a low-risk as it was applied in an established urban area with a strong real estate market [44]. Only 12 of the affected property owners formally objected to the proposed Local Improvement District tax. The South Lake Union Streetcar is owned by the City of Seattle and operated and maintained by a transit agency with representation from the local community.

The last two examples show how a range of procurement and financing models can be organically leveraged through partnerships, based on what is available, to support projects 
focused on urban regeneration using transit infrastructure-and to further expand as the area grows. By starting with available means, further entrepreneurial opportunities are created as the initial segments succeed. From the perspective of the private sector, the benefits from the urban regeneration opportunities are greatest when they are in-volved early, which makes early partnerships and inclusive planning crucial.

\subsubsection{Brightline}

A larger development known as Brightline, Florida has been set up as a purely private rail project using a TAC approach. The project began by leveraging funding from a New York hedge fund based on private sector opportunities around new stations as well as potential fare box returns.

The first stage of the Brightline was developed in partnership with the local and county governments and the local community [7,45]. It opened in late 2017, initially running from Miami to Fort Lauderdale, but with an extension to Orlando International Airport under construction, and further extensions to Disney World and Tampa in planning [46]. There are also plans to build a new line from Los Angeles to Las Vegas.

The latter project includes purchasing 38 acres of land adjacent to the Las Vegas strip for the station and a mixed-use development. It came about via the acquisition of XpressWest, which had secured federal approvals for the rail corridor [47]. The company plans to expand further and describes its business model as "a scalable model for twenty-first century passenger travel in North America" and identifies eight new potential corridors within the United States and Canada [48]. Thus, by taking an organic approach the corridor was eventually completed and the model is now being replicated.

In practice Transit Activated Corridors raise investment for transit through partnerships that grow organically as the land development opportunities are realized and expanded. This minimizes risk for participating private parties and increasingly shifts towards private funding to complete projects. Hence this can reduce government's role especially in terms of having to raise the full capital (often difficult and compared with the ERM/TAC model less value creating) allowing a focus on roles more aligned to the purview of government such as being critical in the delivery partnerships. Government needs to provide creative leadership on zoning, planning integration, and facilitating connections to the wider transit network. Government can also assist with land assembly and risk management in procurement [7], easing the process for private parties to participate and creating new value. Similarly, for the public sector, project-based implementation risk is reduced through sharing with the private sector in this organic stepwise process.

The application of these three principles of effectuation will be a key determinant of the success of the application of the ERM model to deliver Transit Activated Corridors. There are also a range of government tools in urban planning that can be delivered in partnership with developers and investors, and which can help create Transit Activated Corridors.

\section{Theoretical Basis 3: Urban Planning Tools for Fast Transit Corridors and Walkable Station Precincts}

Urban development and infrastructure are best developed when they are part of both a strategic and a statutory framework. The majority of these planning systems, especially in Australia and America, still enable urban sprawl and associated car-based communities and have a lesser focus on enabling transit and urban regeneration. There is however a growing movement to find new ways that urban planning can produce effective corridor transit and TODs. These approaches will be examined in terms of tools for corridor design that facilitate transit and dense urbanism as in a TAC, as well as tools for walkable urban design in the associated TODs. Thus, two more principles have been selected from urban planning tools to help design, finance and deliver Transit Activated Corridors. 


\subsection{Principle 4: Define Transit Activated Corridors}

The first planning tool for creating a high-quality transit system down a corridor is to declare it or zone it in strategic and statutory plans as primarily for transit and dense urbanism. A series of such plans are being developed around the world since Transport for London declared their policy called "Street Families" [49] which sets out the streets that give priority to transit and where density will be given special encouragement. In Melbourne the Victorian Government has a policy called the "Movement and Place" framework which recognizes that streets are not only about moving people from $\mathrm{A}$ to $\mathrm{B}$, but in many contexts also act as places for people and public life. Similar policies have been developed for Auckland, New Zealand, and Western Australia. The movement and place framework enables the "place" prioritization of streets to create walkable, livable centers. In Perth the approach has been proposed to create a "Green Route" in the Metropolitan Region Scheme that requires transit priority and density to be the joint focus along the road. Such routes could be specified as potential Transit Activated Corridors with associated zoning along the corridor.

This approach is increasingly being used in the UK and Europe more generally as part of Sustainable Urban Mobility Plans [50]. The approach is outlined in Table 1 below.

Table 1. Summary of guidelines for sustainable urban mobility plans compared to traditional planning. Source [50].

\begin{tabular}{|c|c|c|}
\hline $\begin{array}{l}\text { Traditional Transport } \\
\text { Planning }\end{array}$ & $>$ & Sustainable Urban Mobility Planning \\
\hline Focus on traffic & $>$ & Focus on people \\
\hline $\begin{array}{l}\text { Primary objectives: } \\
\text { Traffic flow capacity and } \\
\text { speed }\end{array}$ & $>$ & $\begin{array}{l}\text { Primary objectives: Accessibility and quality of life, as well as } \\
\text { sustainability, economic viability, social equity, health and } \\
\text { environmental quality }\end{array}$ \\
\hline Modal-focussed & $>$ & $\begin{array}{l}\text { Balanced development of all relevant transport modes and } \\
\text { shift towards cleaner and more sustainable transport modes }\end{array}$ \\
\hline Infrastructure focus & $>$ & Integrated set of actions to achieve cost-effective solutions \\
\hline $\begin{array}{l}\text { Sectorial planning } \\
\text { document }\end{array}$ & $>$ & $\begin{array}{l}\text { Sectorial planning document that is consistent and } \\
\text { complementary to related policy areas (such as land use and } \\
\text { spatial planning; social services; health; enforcement and } \\
\text { policing; etc.) }\end{array}$ \\
\hline $\begin{array}{l}\text { Short- and medium-term } \\
\text { delivery plan }\end{array}$ & $>$ & $\begin{array}{l}\text { Short- and medium-term delivery plan embedded in a } \\
\text { long-term vision and strategy }\end{array}$ \\
\hline $\begin{array}{l}\text { Related to an } \\
\text { administrative area }\end{array}$ & $>$ & Related to a functioning area based on travel-to-work patterns \\
\hline $\begin{array}{l}\text { Domain of traffic } \\
\text { engineers }\end{array}$ & $>$ & Interdisciplinary planning teams \\
\hline Planning by experts & $>$ & $\begin{array}{l}\text { Planning with the involvement of stakeholders using a } \\
\text { transparent and participatory approach }\end{array}$ \\
\hline $\begin{array}{l}\text { Limited impact } \\
\text { assessment }\end{array}$ & $>$ & $\begin{array}{l}\text { Regular monitoring and evaluation of impacts to inform a } \\
\text { structured learning and improvement process }\end{array}$ \\
\hline
\end{tabular}

A core part of designing TACs would be a set of detailed design options for how a mid-tier transit service like light rail or a trackless tram (see below) could travel at speed down a clearway where road space is available, and then slow down when it enters a station precinct where the design and place focus would be to facilitate walkability and pedestrian activity. The latter part of the road works could be the responsibility of the private sector partners. This would send the signal that dense urban development would be favored as it would have a high-quality transit system linking it to the rest of the city and 
would have a highly attractive urban design quality for attracting people-based activities in and around the stations.

The responsibility to enable TACs would be given to an agency, or cross-agency group, that has both responsibility for delivering transit and delivering urban regeneration. Thus, roads chosen for this category would shift their priority for providing mobility services for through traffic, to a focus on how they could enable quality transit and urban design along the corridor that delivers value to both developers and the community. This would mean more of a focus on accessibility, sustainability and equity as set out in Table 1. Compared with car only lanes such routes could carry the equivalent of six lanes of traffic [51], easing congestion issues while increasing activity along the corridor through transit and urbanism.

\subsection{Principle 5: Walkable and Sustainable Station Precinct Design}

Station precincts must be allowed to be dense and mixed use in the strategic and statutory zoning systems used to enable TACs. There are a large number of design tools created to make station precincts or TODs into "inclusive, safe, resilient and sustainable" places including walkable urban design, solar design, water sensitive design, biophilic design, affordable housing design and most of all integrated design. For instance, there are a number of detailed manuals from the Congress of New Urbanism that set out best practice in these areas [52-55]. Such guidance now needs to be reflected in statutory requirements for station precinct developments along transit corridors. Such requirements also need to consider how new technologies for smart and sustainable systems can enhance various design outcomes. This may include how driverless electric shuttle buses can carry people to the station precincts (providing first and last kilometer solutions) without ruining the walkability qualities of the area [30]. Evidence is showing that Uber (and potentially driverless vehicles) are increasing the vehicle kilometers travelled (VKT) rather than decreasing it as many had anticipated, causing greater congestion and accessibility issues [56]. To counter this trend will require a different approach to mobility and TACs are likely to be part of this.

\section{Applying Transit Activated Corridor Development with Mid-Tier Transit}

A research project as part of the Sustainable Built Environment National Research Centre (SBEnrc) has been developed with a series of partners seeking to deliver a mid-tier transit-based TAC using the ERM approach. It was given a significant boost when a new transit technology was discovered that we have called a "Trackless Tram". The trackless tram systems (TTS) have taken six innovations from high-speed rail, put them in a carriage bus - or tram like vehicle - with stabilization through bogeys and optical guidance systems, that not only mean it is largely autonomous (though not completely driverless), but it is also enabled to move at speed down a road with the ride quality of a light rail. Being electric through batteries and with no need for steel tracks, it is significantly cheaper and easier to implement than a light rail and significantly better than BRT at creating urban land value uplift. Research was conducted on assessing this technology [51] and the conclusions are presented in Table 2. 
Table 2. Indicative comparison of characteristics of corridor based urban rapid transit systems.

\begin{tabular}{lccc}
\hline Characteristic & $\begin{array}{c}\text { Bus Rapid Transit } \\
\text { (BRT) }\end{array}$ & $\begin{array}{c}\text { Light Rail Transit } \\
\text { (LRT) }\end{array}$ & $\begin{array}{c}\text { Trackless Tram } \\
\text { System (TTS) }\end{array}$ \\
\hline Speed and Capacity & $\checkmark$ & $\checkmark \checkmark$ & $\checkmark \checkmark$ \\
\hline Ride Quality & $x$ & $\checkmark \checkmark$ & $\checkmark \checkmark$ \\
\hline $\begin{array}{l}\text { Land Development } \\
\text { Potential }\end{array}$ & $x$ & $\checkmark \checkmark$ & $\checkmark \checkmark$ \\
\hline Cost & $\checkmark$ & $x$ & $\checkmark$ \\
\hline $\begin{array}{l}\text { Disruption during } \\
\text { construction period }\end{array}$ & $\checkmark$ & $x$ & $\checkmark$ \\
\hline Implementation Time & $\checkmark$ & $x$ & $\checkmark \checkmark \checkmark$ \\
\hline Overall & $\checkmark$ & $\checkmark \checkmark$ & $\checkmark$ \\
\hline
\end{tabular}

The assessment provided above highlights that TTS has the potential to stimulate urban redevelopment potential just as well as good light rail and hence can enable the delivery of TACs. This will require assessment in different cities, but an approach is suggested using the five principles developed from the three entrepreneurial principles and the two urban planning tools. This enables a high-level approach to assess the potential to deliver very efficient and effective Transit Activated Corridors using a mid-tier transit as the catalyst. The core requirements from the five principles for TAC are applied to the three options of BRT, LRT and TTS and are set out in Table 3. This enables us to see how well the new technology of TTS promises to facilitate a TAC.

Table 3. Comparison of TAC characteristics for corridor based urban rapid transit systems of BRT, LRT and TTS.

\begin{tabular}{|c|c|c|}
\hline \multicolumn{3}{|c|}{ Characteristic 1: Ability to facilitate partnership-driven planning } \\
\hline BRT & $\begin{array}{l}\text { BRT is able to achieve partnership driven planning, however partnerships are generally transport-centric } \\
\text { given the lesser urban regeneration ability achieved by traditional bus-based schemes. }\end{array}$ & $\checkmark$ \\
\hline LRT & $\begin{array}{l}\text { LRT is able to bring transit, land development and community interests to the table and this has been } \\
\text { demonstrated around the world, including in the case studies above. }\end{array}$ & $\checkmark \checkmark$ \\
\hline TTS & $\begin{array}{l}\text { TTS are able to bring the same interests together as LRT to plan a transit project financed by urban } \\
\text { regeneration, however TTS can enable the inclusion of far more parties than under the recent welfare finance } \\
\text { model of most light rail. Projects do not need to be "Tokyo" in scale to get started, and have less risk. An } \\
\text { inclusive, bottom-up, community-engaged planning approach can be achieved with the less expensive } \\
\text { trackless trams, rather than only being considered by the top-down stakeholders. }\end{array}$ & $\checkmark \checkmark \checkmark$ \\
\hline \multicolumn{3}{|c|}{ Characteristic 2: Ability for value creation through urban regeneration } \\
\hline BRT & Bus-based systems have had less urban regeneration success in most cases. & $x$ \\
\hline LRT & $\begin{array}{l}\text { Light rail has been successful in attracting investment and urban regeneration around its lines, especially } \\
\text { given its fixed nature, however urban regeneration is best achieved if land development is used as the } \\
\text { cornerstone of transit finance such as proposed here. }\end{array}$ & $\checkmark \checkmark$ \\
\hline TTS & $\begin{array}{l}\text { Ability to be used like light rail, particularly through an entrepreneurial financing process to ensure urban } \\
\text { regeneration is undertaken, but at lower cost to the entrepreneurs and thus is more likely. }\end{array}$ & $\checkmark \checkmark$ \\
\hline \multicolumn{3}{|c|}{ Characteristic 3: Ability for organic resourcing through staged financing } \\
\hline BRT & $\begin{array}{l}\text { The lack of strong urban regeneration attraction created by BRT systems creates a lack of investor incentive } \\
\text { for the finance of new lines. }\end{array}$ & $x$ \\
\hline LRT & Has been achieved in a number of cities, highlighted in case studies above. & $\checkmark \checkmark$ \\
\hline TTS & $\begin{array}{l}\text { Organic resourcing through staged financing would be similar to the LRT as in the case studies outlined } \\
\text { above. At each stage of financing the two parts of the TAC, the trackless tram and the chain of TODs could } \\
\text { be financed with steps assessed for land value uplift, patronage and other benefits and costs, before } \\
\text { proceeding to the next stages. }\end{array}$ & $\checkmark \checkmark$ \\
\hline
\end{tabular}


Table 3. Cont.

\begin{tabular}{cl}
\hline Characteristic 4: Ability to service strategic plans (TAC route) \\
\hline BRT & $\begin{array}{l}\text { If strategic plans are developed mode agnostically, BRT is competitive on infrastructure cost and speed if } \\
\text { given priority. However, it will not achieve urban regeneration outcomes. }\end{array}$ \\
\hline LRT & $\begin{array}{l}\text { If strategic plans are developed mode agnostically, LRT is competitive on capacity per vehicle, speed and } \\
\text { ability to attract regenerative investment. }\end{array}$ \\
\hline TTS & $\begin{array}{l}\text { If strategic plans are developed mode agnostically, TTS can enable the capacity and speed of LRT but cost } \\
\text { much less. This is likely to open up the potential for many more strategic routes and help create an overall } \\
\text { network with far greater overall benefits. }\end{array}$ \\
\hline Characteristic 5: Ability for integrated application of TOD design tools \\
\hline BRT & The same TOD principles can be applied but without private investment they rarely happen. \\
\hline LRT & $\begin{array}{l}\text { Able to utilize best-practice integrated TOD design from light rail projects to achieve walkable, } \\
\text { people-centric transit precincts. }\end{array}$ \\
\hline TTS & $\begin{array}{l}\text { Design tools for TODs would be just as effective in station precincts around trackless trams as around LRT } \\
\text { except the cost of the infrastructure is much less (no overhead catenary and no steel tracks). }\end{array}$ \\
\hline
\end{tabular}

The high-level assessment would suggest there is a very high capability of a trackless tram system and a light rail to enable a TAC to be created with a quality transit corridor and a chain of high-quality station precincts linked to it. These results are summarized in Table 4.

Table 4. Indicative comparison of characteristics of corridor based urban rapid transit systems in terms of entrepreneurship and urban planning factors supporting a Transit Activated Corridor.

\begin{tabular}{lccc}
\hline $\begin{array}{l}\text { Characteristics in Terms } \\
\text { of Ability to Use }\end{array}$ & $\begin{array}{c}\text { Bus Rapid } \\
\text { Transit (BRT) }\end{array}$ & $\begin{array}{c}\text { Light Rail Transit } \\
\text { (LRT) }\end{array}$ & $\begin{array}{c}\text { Trackless Tram } \\
\text { System (TTS) }\end{array}$ \\
\hline Partnerships & $\checkmark$ & $\checkmark \checkmark$ & $\checkmark \checkmark \checkmark$ \\
\hline $\begin{array}{l}\text { Value Creation in Urban } \\
\text { Regeneration Potential }\end{array}$ & $x$ & $\checkmark \checkmark$ & $\checkmark \checkmark$ \\
\hline $\begin{array}{l}\text { Organic Resourcing } \\
\text { through Staged Financing }\end{array}$ & $x$ & $\checkmark \checkmark$ & $\checkmark \checkmark$ \\
\hline Strategic TAC Route & $\checkmark$ & $\checkmark$ & $\checkmark \checkmark$ \\
\hline Design Tools for TODs & $x$ & $\checkmark$ & $\checkmark \checkmark$ \\
\hline Overall & $\checkmark$ & $\checkmark \checkmark$ & $\checkmark \checkmark \checkmark$ \\
\hline
\end{tabular}

\section{Conclusions}

Growing cities around the world are looking for new ways to deliver transit and urban redevelopment. This paper suggests a new option called a Transit Activated Corridor (TAC) and sets out how best to achieve them using five principles drawn from entrepreneurship theory and urban planning:

1. Create partnerships from the start, that suggests for TAC the need for partnerships between government, community and the private sector which can leverage such entrepreneurial approaches similar to the historic role of entrepreneurs in creating train and tram corridors, and the emerging models for involving the private sector in rail developments, especially involving City Deals;

2. Value creation rather than prediction, which suggests for TAC taking value creation opportunities through involvement of private sector financing of land development rather than predicting transit outcomes as in current transit planning;

3. Begin with available means rather than pre-determined ends, suggesting that TAC could use available resourcing from land development in organic steps to stage the financing; 
4. Define Transit Activated Corridors, that suggests a high-level strategic plan to develop Transit Activated Corridors (like the European Sustainable Urban Mobility Plans) with statutory mechanisms that require the delivery of transit priority as well as dense, urban regeneration, and providing a delivery agency focussed on this task; and

5. Walkable and sustainable station precinct design, that would mean a series of statutory design requirements for the station precincts to be high quality designed TODs for walkability, affordability and sustainability.

All these require the private sector to be actively involved from the beginning of the planning process, providing the opportunity to collaboratively shape and capture benefits from transit activation along the corridor, creating the basis for the private sector to contribute financing given the attractive development opportunities that exist.

When the five principles were applied to a high-level assessment of new mid-tier transit technology, it showed that these lower cost new technology options are likely to help with the design, financing and delivery of a Transit Activated Corridor down urban streets.

Author Contributions: Author contributions were as follows: S.D.-S. (30\%), P.N. (25\%), D.C. (20\%), K.H. (20\%), M.M. (5\%). All authors have read and agreed to the published version of the manuscript.

Funding: This research was funded by the Sustainable Built Environment National Research Centre, Project 1.74. In addition, Sebastian Davies-Slate received PhD scholarship funding from the CRC for Low Carbon Living.

Informed Consent Statement: Not applicable.

Conflicts of Interest: The authors declare no conflict of interest.

\section{References}

1. Calthorpe, P. The Next American Metropolis: Ecology, Community, and the American Dream; Princeton Architectural Press: Hudson, NY, USA, 1993.

2. Cervero, R.; Ferrell, C.; Murphy, S. Transit-Oriented Development and Joint Development in the United States: A Literature Review; TCRP Research Results Digest Number 52; Transportation Research Board, National Research Council: Washington, DC, USA, 2002.

3. Belzer, D.; Autler, G. Transit Oriented Development: Moving from Rhetoric to Reality; Brookings Institution Center on Urban and Metropolitan Policy: Washington, DC, USA, 2002.

4. Newton, D. TAD or TOD? A Look at the W at Hollywood and Vine". Streetsblog LA. 31 March 2010. Available online: https: / /la.streetsblog.org/2010/03/31/tad-or-tod-a-look-at-the-transit-oriented-development-at-hollywood-and-vine/ (accessed on 1 June 2021).

5. Renne, J.L.; Bartholomew, K.; Wontor, P.; Transportation Research Board; Transit Cooperative Research Program Legal Program. Transit-Oriented and Joint Development: Case Studies and Legal Issues; National Academies Press: Washington, DC, USA, 2011.

6. Ewing, R.; Bartholomew, K. Pedestrian- and Transit-Oriented Design; Urban Land Institute and American Planning Association: Washington, DC, USA, 2013.

7. Newman, P.; Kenworthy, J. The End of Automobile Dependence: How Cities are Moving Beyond Car-based Planning; Island Press: Washington, DC, USA, 2015.

8. Davies-Slate, S.; Newman, P. Partnerships for Private Transit Investment-The History and Practice of Private Transit Infrastructure with a Case Study in Perth, Australia. Urban Sci. 2018, 2, 84-104.

9. Glaeser, E.L. The challenge of urban policy. J. Policy Anal. Manag. 2011, 31, 111-122. [CrossRef]

10. Winch, G. Managing Construction Projects: An Information Processing Approach; Wiley: Hoboken, NJ, USA, 2002.

11. Newman, P.; Kosonen, L.; Kenworthy, J. Theory of urban fabrics: Planning the walking, transit/public transport and automobile/motor car cities for reduced car dependency. Town Plan. Rev. 2016, 87, 429-458. [CrossRef]

12. Dittmar, H.; Ohland, G. (Eds.) The New Transit Town: Best Practices in Transit-Oriented Development; Island Press: Washington, DC, USA, 2004.

13. Newman, P.; Davies-Slate, S.; Jones, E. The Entrepreneur Rail Model: Funding urban rail through majority private investment in urban regeneration. Res. Transp. Econ. 2018, 67, 19-28. [CrossRef]

14. McIntosh, J.; Newman, P.; Glazebrook, G. Why Fast Trains Work: An Assessment of a Fast Regional Rail System in Perth, Australia. J. Transp. Technol. 2013, 3, 37-47. [CrossRef]

15. Sharma, R.; Newman, P. Land Value Capture Tools: Integrating Transit and Land Use through Finance to Enable Economic Value Creation. Mod. Econ. 2020, 11, 938-964. [CrossRef]

16. Yang, J.; Alterman, R.; Li, B. Value Capture beyond Public Land Leasing: Funding Transit and Urban Redevelopment in China's Pearl River Delta; Lincoln Institute of Land Policy: Cambridge, MA, USA, 2020. 
17. Ndlovu, V.; Newman, P. How Would the Trackless Tram System and Public-Private Partnership (PPP) Apply to Bulawayo? Curr. Urban Stud. 2021, 9, 17-30. [CrossRef]

18. Cervero, R. Rail Transit and Joint Development: Land Market Impacts in Washington, D.C. and Atlanta. J. Am. Plan. Assoc. 1994, 60, 83-94. [CrossRef]

19. Hitt, M.; Ireland, D.; Sirmon, D.; Trahms, C. Strategic Entrepreneurship: Creating Value for Individuals, Organisations and Society; Academy of Management Executive: New York, NY, USA, 2011.

20. Rauch, A.; Wiklund, J.; Lumpkin, G.T.; Frese, M. Entrepreneurial Orientation and Business Performance: An Assessment of Past Research and Suggestions for the Future. Entrep. Theory Pract. 2009, 33, 761-787. [CrossRef]

21. Link, A.; Link, J. Government as Entrepreneur; Oxford University Press: Oxford, UK, 2009.

22. Olsson, A.; Westlund, H.; Larsson, I.; Kourtit, K.; Nijkamp, P.; Stouch, R.R. The Rise of the City: Spatial Dynamics in the Urban Century; Edward Elgar Publishing: Cheltenham, UK; Northampton, MA, USA, 2015.

23. Link, A.N.; Siegel, D. (Eds.) Innovation, Entrepreneurship, and Technological Change; OUP: Oxford, UK, 2007.

24. Harvey, D. From Managerialism to Entrepreneurialism: The Transformation in Urban Governance in Late Capitalism. Geogr. Ann. Ser. B Hum. Geogr. 1989, 71, 3-17. [CrossRef]

25. Frederick, H.; O'Connor, A.; Kuratko, D. Entrepreneurship: Theory, Process, Practice; Cengage Learning: South Melbourne, VIC, Australia, 2013.

26. Sarasvathy, S. Effectuation: Elements of Entrepreneurial Expertise; Edward Elgar Publishing: Northampton, MA, USA, 2009.

27. Zhao, Z.; Vardhan Das, K.; Larson, K. Joint Development as a Value Capture Strategy for Transportation Finance. In Value Capture for Transportation Finance: Technical Research Report; Centre for Transportation Studies, University of Minnesota: Minneapolis, MN, USA, 2009.

28. Clark, G.; Clark, G. Nations and the Wealth of Cities: A New Phase in Public Policy; Centre for London: London, UK, 2014.

29. Australian Government. "Delivering City Deals: The Fact Sheet". Available online: https://infrastructure.gov.au/cities/citydeals / files /City-Deal-Process-factsheet.pdf (accessed on 17 January 2019).

30. Glazebrook, G.; Newman, P. The City of the Future. Urban Plan. 2018, 3, 1-20. [CrossRef]

31. National Audit Office. Devolving Responsibilities to Cities in England: Wave 1 City Deals; Report by the Comptroller and Auditor General: London, UK, 2015.

32. Clark, G.; Moonen, T. Creating Great Australian Cities; The Property Council of Australia and Urbis: Newcastle, NSW, Australia, 2018.

33. Metro Rail Policy; GoI, Government of India: Delhi, India, 2017.

34. Levinson, D.; Marshall, W.; Axhausen, K. Elements of Access: Transport Planning for Engineers, Transport Engineering for Planners; Network Design Lab: Sydney, NSW, Australia, 2017.

35. Downs, A. Stuck in Traffic: Coping with Peak-Hour Traffic Congestion; Brookings Institute: Washington, DC, USA, 1992.

36. Litman, T. Generated Traffic and Induced Travel: Implications for Transport Planning. A Report from the Victoria Transport Policy Institute. 2017. Available online: https:/ / trid.trb.org/view/1489046 (accessed on 6 July 2021).

37. Cervero, R. The Transit Metropolis-A Global Inquiry; Island Press: Washington, DC, USA, 1998.

38. Saito, T. Japanese Private Railway Companies and their Business Diversification. Japan Railway and Transport Review. January 1997. Available online: https:/ / www.ejrcf.or.jp/jrtr/jrtr10/f02_sai.html (accessed on 6 July 2021).

39. Ellicott, S.; Pagan, L. Impact Analysis of San Francisco's Property \& Business Improvement Districts (CBDs/BIDs). Available online: https:/ / oewd.org/sites/default/files/FileCenter/Documents/786-CBD\%20BID\%20Eval\%20Report\%20FY\%2012-13\% 20updated.pdf (accessed on 11 January 2019).

40. Levenda, A.; Huang, C. The Pearl District an Urban Development Case Study of the Pearl District and Brewery Blocks in Portland; CDCB: Portland, OR, USA, 2015.

41. Dawkins, C.J.; Nelson, A.C. State Growth Management Programs and Central-City Revitalization. J. Am. Plan. Assoc. 2003, 69, 381-396. [CrossRef]

42. Markusen, A. Urban Development and the Politics of a Creative Class: Evidence from a Study of Artists. Environ. Plan. A Econ. Space 2006, 38, 1921-1940. [CrossRef]

43. Weitz, J.; Moore, T. Development inside Urban Growth Boundaries: Oregon's Empirical Evidence of Contiguous Urban Form. J. Am. Plan. Assoc. 1998, 64, 424-440. [CrossRef]

44. Mathur, S.; Smith, A. A Decision-Support Framework for Using Value Capture to Fund Public Transit: Lessons from ProjectSpecific Analyses. Mineta Transportation Institute. 2012. Available online: https://transweb.sjsu.edu/sites/default/files/1004 -decision-support-framework-value-capture-public-transit-funding.pdf (accessed on 1 June 2021).

45. Renne, J.L. Make Rail (and Transit-Oriented Development) Great Again. Hous. Policy Debate 2017, 27, 472-475. [CrossRef]

46. Brightline. Brightline Florida. Available online: https://www.gobrightline.com/florida-expansion (accessed on 31 May 2021).

47. Brightline. Brightline to Build Express Intercity Passenger Rail Connecting Southern California and Las Vegas. Media Release. 18 September 2018. Available online: http:/ / press.gobrightline.com/showPressRelease/100055086 (accessed on 18 September 2018).

48. Securities and Exchange Commission. Form S-1 Registration Statement under the Securities Act of 1933, Virgin Trains USA LLC. Available online: https://www.sec.gov/Archives/edgar/data/1737516/000114036118043289/s002218x4_s1.htm (accessed on 31 May 2021). 
49. Transport for London. London's Street Family: Theory and Case Studies. Available online: https://tfl.gov.uk/corporate/ publications-and-reports/rtf-supporting-documents (accessed on 31 May 2021).

50. Eltis. Guidelines for Sustainable for Urban Mobility Plans, European Commission's Directorate General for Mobility and Transport. 2016. Available online: https:/ / www.eltis.org/mobility-plans/sump-guidelines (accessed on 6 July 2021).

51. Newman, P.; Hargroves, K.; Davies-Slate, S.; Conley, D.; Verschuer, M.; Mouritz, M.; Yangka, D. The Trackless Tram: Is It the Transit and City Shaping Catalyst We Have Been Waiting for? J. Transp. Technol. 2019, 9, 31-55. [CrossRef]

52. Talen, E. Congress for the New Urbanism. In Charter of the New Urbanism, 2nd ed.; McGraw-Hill Education: New York, NY, USA, 2013.

53. Tachieva, G. Sprawl Repair Manual, 2nd ed.; Island Press: Washington, DC, USA, 2013.

54. Benfield, F.; Terris, J.; Vorsanger, N. Solving Sprawl: Models of Smart Growth in Communities across America; Natural Resources Defense Council: New York, NY, USA, 2001.

55. Dunham-Jones, E.; Williamson, J. Retrofitting Suburbia: Urban Design Solutions for Redesigning Suburbs; John Wiley \& Sons: Hoboken, NJ, USA, 2008.

56. Schaller, B. The New Automobility: Lyft, Uber and the Future of American Cities; Schaller Consulting: Brooklyn, NY, USA, 2018. 